\title{
The Auckland School of Music, Post-Modernism \& Nervous Laughter
}

Kate Linzey, School of Creative Technologies, Weltec, Wellington

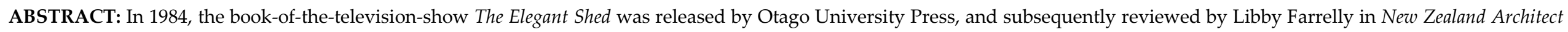

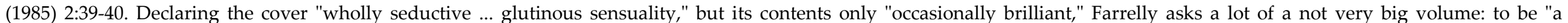

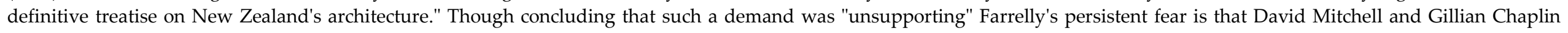
lacked a "valiant idea."

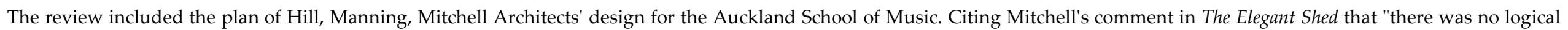
connection between the side of a grand piano and the shape of a noise deflecting wall," Farrelly warns that such arbitrary aesthetics condemns architecture to mere "applique."

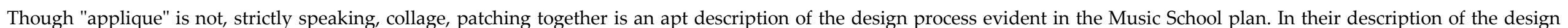

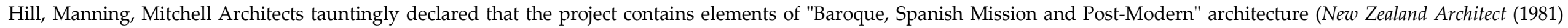
5/6:1-3), and suggested that their transition from being "straight-line modernists" to "sensuous and baroque... [is] not unexpected in middle age."

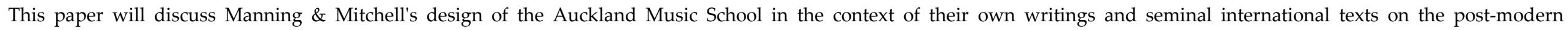

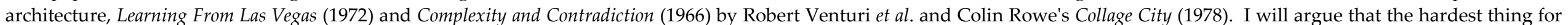
architecture to bear/bare, especially New Zealand architecture, is a sense of humour.

As a child of the 1980s and 1990s it is hard not to just give up with despondency when faced with Post-Modernism, and the "baby boom" generation that invented it. Peter Wood suggested that we need to excuse the "baby boomers" seeing their actions as a consequence of their post-war social burden. ${ }^{1}$ However, having grown up just in time to catch all forms of user-pays, such as my University fees, yet simultaneously been told that "you kids" have it so much easier these days, it is a little hard to stomach. In looking

${ }^{1}$ Wood "Watershed" p 74. for an inspirational topic to discuss from this era, the Auckland University School of Music appears as a shinning example of how postmodernism was not just the expression of gross capitalism. Similarly, reading David Mitchell's The Elegant Shed (1984), there is a growing suspicion, that like the hijacking of the aesthetics of socialist Modernism by capitalism after World War II, the postmodern has not always commanded who and how it represents culture.

After World War II the tertiary student population swelled - on nominal fees and substantial student allowances. At first this population consisted of returning servicemen, but this was quickly augmented by the emerging "baby-boom" generation. Marked demographically beginning around 1945 and ending in 1960, the population blip arrived at New Zealand universities between 1963 and 1978, and this is recorded in their buildings. Massive Brutalist concrete structures, designed predominantly by the Ministry of Works architects office. Built from the mid 1950s to the 1970s, these buildings reflect a first wave post-modernism. Motivated by a socialist reaction to the 
commercialising of pre-war Modern aesthetics, and led by the English architects Alison and Peter Smithson, this raw concrete architecture maintained Modernism's principles of structural clarity, functionalism and economy, but added the preference for material weightiness to embed structures, almost naturalistically, into their contexts.

At the University of Auckland the last buildings to be upgraded in the post-war expansion were the Architecture, Fine Arts and Music School's. Between the two designs for the Architecture School and the Music School, the shift to "post-modernism" proper, is clearly delineated. The former designed by Kingston Reynolds Thom and Allardice, and completed by 1980, still expresses the hefty honesty of Brutalism, however a new form of humanism has appeared in the horse-shoe planning, which opens the building to a central courtyard. The latter, designed while the Architecture School was being built, by Manning Mitchell and Hill, demonstrates a fundamentally different attitude to materiality. While the courtyard form has merely become more distinct and elaborate, surrounded by tiers of romantically planted and pergola-ed balconies, the materiality has become light, colourful and, for lack of a better word, cheap.

Designed in 1979-80, and presented to the public as a model, made by Gill Matthewson and Paul Armstrong in 1981, the project received several awards including the AAA Monier Design Award in 1980, the AHI Fibreglass Environmental Design Award in $1986,{ }^{2}$ and the NZIA National Award in 1987. ${ }^{3}$ Completed in 1987, the design reappears in several discussions in the New Zealand Architect, where the problems of a difficult site, the noise from Symonds Street, and the tight project budget are often enumerated. However, the School of Music has been recognised, almost unanimously, as a successful design, if not the successful design, of the 1980s.

The School of Music, like the Architecture School before it, and the Thomas Building across the road, was planned to create a sheltered internal space. ${ }^{4}$ Where the Architecture School produces a space

${ }^{2}$ Manning/Mitchell Architects "A.H.I. Fibreglass

Environmental Design Award in 1986" p 20.

${ }^{3}$ Walker Exquisite Apart p 158.

${ }^{4}$ Mitchell cites the Thomas Building by Kingston Reynolds Thom and Allardice (106-) Mitchell "Looking Inwards" pp 27-28. opening at each end and staggered over three levels, the Thomas Building forms a hidden hanging garden. The Music School uses this space to create an amphitheatre edged by a cloistered walkway. The often noted curved wall façade facing Symonds Street acts as a filter between the speed of the main street and the much slower, indeed idyllic, compound. The library to the north and west is single storey, topped by a roof garden, while the teaching spaces and offices are stacked toward the south. The three storeys present balconies of planters and trellis to the courtyard at a domestic scale. The effect is distinctly Mediterranean, but in an Auckland suburban kind of a way. The curving forms that dominate the design were said to have "first appeared with a practical reason"5 however this is quickly mixed into a series of poetic analogies. In a complicated twisting of language Mitchell suggests the initial curved façade was to be in glass:

When Jack Manning and I were designing the Music School ... we knew there was no logical connection between the side of a grand piano and the shape of a noise-reflecting street wall, but artistically it seemed perfectly reasonable for one to mirror the other ... So the street wall is turned in the architects' minds from glass

${ }^{5}$ Manning, Mitchell and Hill, Architects "Faculty of Music Building, University of Auckland" p 1. 
to concrete as its noise-controlling role is understood. ${ }^{6}$

The curved glass wall was like the façade of the Willis Faber and Dumas Building by Foster Associates, completed in 1975, though the more common reference is to the subtle internal curves of Alvar Aalto's Villa Mairea (1937-39). ${ }^{7}$ Called Baroque, and associated with the lines of a grand piano, the architects at times also described the plan as the curves of an ear. Kent Dadson described it beautifully as a composition in two sonatas, shell like with "melodic turns."8

In their 1986 building report Manning/Mitchell (Hill left the partnership after 1981) stated that the Music School demonstrated the viability of "lightweight low-cost materials, instead of the more common heavy materials and high-energy air conditioning used in noise-controlled buildings."9 Similarly, in his "Appraisal of the Music School" Graeme Robertson commends Manning/Mitchell for breaking with "permanence," as a clear reaction against

${ }^{6}$ Mitchell \& Chaplin Elegant Shed pp 96-97.

${ }^{7}$ Matthewson, Pers Comm.

${ }^{8}$ Dadson "Schola Musica" p 34.

${ }^{9}$ Manning/Mitchell "Report by Manning/Mitchell

Registered Architects" p 21.
Brutalism. To avoid framing impermanence as a concession to the limits of the project, Robertson questions whether the weathering of concrete in Auckland is as successful as in Christchurch, making reference to the notable Christchurch architects Peter Bevan and Miles Warren, leaders in the Brutalist style. "Here [Robertson suggests] we have an inherently Auckland building of the 1980s. A building that does not exhibit qualities of permanence in the normal sense."10 Flimsiness, the discussion suggests, is an Auckland aesthetic trait, however a quick digression comparing establishment budgets to running, or maintenance budgets, reattaches flimsiness to an economic necessity. With Gloss, the definitive Auckland television series about to screen (1987-90), cheap and flashy, but with higher hidden costs, would come to provincially define Auckland.

While not meaning to undermine the importance of Jack Manning in this story of the Music School, it is David Mitchell, and his cultivation of Post-Modern architecture in New Zealand that is the focus of this paper. After graduating, Mitchell returned to the Auckland School of Architecture as a lecturer

${ }^{10}$ Robertson "Appraisal of the Music School" p 24. in the "Brick Studio" in 1972. Teaching with notable Auckland architects such as Mike Austin and Nick Stanish, the "Brick Studio" cultivated an avant garde position. The Modernists, such as Allan Wild, may have held sway at the institutional centre, but on its outer edge the Brick Studio entertained radical ideas such as vertically-streamed studios and architectural referentially. Travelling in America in the 1970s, Mitchell made a pilgrimage to Las Vegas, Robert Venturi and Denise Scott Brown's designated home of Post-Modernism. ${ }^{11}$ He left teaching in the 1987; as long as it took to finish the Music School project. Meanwhile Manning/Mitchell produced the Majestic Centre, finished in 1991, and, practising on his own, Mitchell completed the Gibbs House, which graces the cover of the Elegant Shed, in 1984. Between 1992 and 2000 he took to the waves, sailing via Japan to work in Hong Kong, returning to Auckland to design the New City Art Gallery completed in 1995. As of 2005 Mitchell had received ten awards in architecture, three of which were from the NZIA, the most prestigious of these being an NZIA Gold Medal for Achievement in

\footnotetext{
${ }^{11}$ Mitchell "The Slob City Impulse" p 267.
} 


\section{Architecture. ${ }^{12}$}

Already holding a prominent position amongst architects, Mitchell made it to national television in 1984 with the screening of "The Elegant Shed": a six part segment within the long running Kaleidoscope series. ${ }^{13}$ For the show Mitchell sports a friendly Amish style beard, which belies his particular gift for critical asides and cutting analogies. On departing from Christchurch, for example, he makes pleased gestures describing the forms of Paul Pascoe's 1960 Airport Building, but adds that it has "the vacuous festive air of flight in the 1950s and 60s - which still exists in Christchurch architecture." Perhaps, as a post-modernist, Mitchell did not see vacuity as derogatory accusation, however the quip did not make it into the book. In a 2005 interview with Mitchell, Diana Wichtel tries to sum up his personality:

[If] the mind of the architect is a foreign country. If David Mitchell is a representative example... it is perverse and seemingly committed to discomfort. ${ }^{14}$

\footnotetext{
12 "Awards" n.p.

${ }^{13}$ The segment took an half hour between over the month of March, and beginning of April, 1984.

${ }^{14}$ Wichtel "'Making places sing."
}

In the same interview, declaring "The Elegant Shed" "idiosyncratic" Wichtel historicises the book and the series as "both dated (Mitchell brings an acute pop culture sensibility, some serious period whiskers, chest hair and chains to the task - the architect as showman)." However this overlooks the reality that the Elegant Shed is still the closest New Zealand has come to an on-shore treatise on architecture. For Mitchell's book is not, strictly speaking an history, but a carefully crafted mythology. As he stated in the interview:

The book was a reality, says Mitchell. "It isn't just a statement of the facts, which is a pompous and pious way of saying it's a bit exaggerated here and there. Not entirely true, but mythically good. I'll take the myths every time."

There is a growing mythology, not just in what the book said, but in what it failed to record from the television series. The book of the television show, is not quite a transcript, nor could it record such delightful moments as the expression on Miles Warren's face when Mitchell asks him to draw the plan of the Dorset Street Flats. The publication of drawings in the book feels pointed. Chapters on "The Auckland Style" and "The Christ's College Connection" are dotted with drawings, mostly floor plans. But drawings are largely missing from the middle sections "The Architecture of Display" and "Buildings Against the Landscape." Drawings reappear in the concluding chapter "Risky Horizons" where Mitchell's own designs are discussed along with "paper architecture" projects by Rewi Thompson, Pete Bossley and Noel Lane. To contextualise these projects, Mitchell cites Mies van der Rohe's 1919 "Skyscraper" to demonstrate how a drawn idea can change architecture. Of these designs, only the Music School building is shown in plan.

At the time of publication the Elegant Shed was reviewed by Libby Farrelly for New Zealand Architect. ${ }^{15}$ Declaring the cover "wholly seductive ... glutinous sensuality," but its contents only "occasionally brilliant," Farrelly felt that it failed to produce "a definitive treatise on New Zealand's architecture." Though concluding that such a demand was "unsporting;" Farrelly's persistent fear was that David Mitchell and Gillian Chaplin lacked a "valiant idea." In repost, in his "comments" on the design of the School of Music, Paul Walker, critiquing Farrelly's critique, found that the Elegant Shed

${ }^{15}$ Farrelly "At Last - the great New Zealand Hovel" p 39. 
entreats a "brave declaration that "architecture is art."'16 It is perhaps the attention to drawing which led Walker, against Farrelly, to see such a declaration. Certainly, dotted throughout the text, Mitchell compares architecture to painting and poetry, citing Don Peebles, Ben Nicholson, Rita Angus and quoting Wynstan Curnow. Other subsequent citation have focused on Mitchell's production of a "myth" focusing on the "shed" itself. Peter Wood ${ }^{17}$ and Robin Skinner, ${ }^{18}$ elaborate on Mitchell's definition of New Zealand Modern architecture as, in Mitchell's own words, the domain of "good keen men." The book does seem to begin and end with primitive huts in the landscape: from baches on Rangitoto to Mitchell's own Begg Beach House, Opito. The "man alone" which Mitchell cited, immortalised in the photograph in the Auckland Architecture School Library, but now exposed, by Skinner's fuller telling, ${ }^{19}$ as not so alone at all, has hung phantom-like within the discourse of New Zealand architecture.

${ }^{16}$ Walker "University of Auckland Music School: a blank wall' p 33.

17 Wood "Watershed" pp 72-81.

${ }^{18}$ Skinner "Whare in the Bush" p 57.

${ }^{19}$ Skinner "The Whare in the Bush" pp 56-73.
The myth of "good keen men," one which supported Modernist principles of architecture as basic and "honest" building, is however not the point of the Elegant Shed. Mitchell actually starts with "hometowns": coastal towns, Hokitika or Thames, and cow towns, Paeroa and Bulls, and ends with Noel Lane's "Hometown Museum: Helensville Rubbish Tip." What Mitchell most consistently asserts is the necessity for architects to examine vernacular traditions, whether folk or commercial, and he does not denigrate the Modernists for doing likewise, only critiques their failure to look also at contemporary urban conditions.

In the 1979 essay "Slob City Impulse," citing both his own trip to Las Vegas and the Venturi, Scott-Brown \& Izenour text, Mitchell rails against the "common sense phrases" of Modern functionalism: "good planning" and "sensitive use of materials," declaring "I think that good planning and commonsense often demean architecture. When you hear an architect say that something "works," you can be pretty sure that's all it does." 20 You would have to be "glum" to read the book, Mitchell implies, so you'd best go look for Slob City in

${ }^{20}$ Mitchell "Slob City Impulse" p 268. your own home town: Barry's Point Road, and Great South Road. The essay, structured as "four or five floors of junk culture" presents architecture as "mechanism," "collection," "collision" and "facade," "tenuously linked" as Slob City "just a useful way of pulling together ideas that interest me. And I love it." In conclusion Mitchell suggest that professional architecture shares "marginal opportunity" with "wide responsibility" which lead the "hows" to overwhelm the "whys": "It's like discussing the tone of a musician, rather than the music he is playing." 21

"Slob City Impulse" and the Elegant Shed make repeated references to Learning from Las Vegas. From the overt, as mentioned above, to the elaborative:

We used to navigate the highway by landmarks, looking for steeples and monuments poking over the hill. We took our bearings from the larger objects around us. Now we do it by reading signs over motorways, and if we look around unduly, and steer in the direction we think we are going, then in a flask we are spiralling down some off-ramp that leads into the never-never. ${ }^{22}$

\footnotetext{
${ }^{21}$ Mitchell "Slob City Impulse" p 271
}

${ }^{22}$ Mitchell Elegant Shed, p 14 
From Learning From Las Vegas:

A driver thirty years ago could maintain a sense of orientation in space. At the simple crossroad a sign with an arrow confirmed what was obvious. One knew where one was. When the crossroads becomes a cloverleaf, one must turn right to turn left... the driver has no time to ponder paradoxical subtleties within a dangerous, sinuous maze. He or she relies on signs for guidance - enormous signs in vast spaces at high speeds. ${ }^{23}$

Needless to say New Zealand still has few clover leaf intersections, and we would turn left to turn right (a bit like Roger Douglas), but the reference is clear and the implications are the same. In paraphrasing for us Learning From Las Vegas, Mitchell focuses on its central demand, not that architecture merely adopt motorway signage, but that we reconsider how we look at things. The façades of Las Vegas, which Mitchell equates easily to the fake-fronts on hometown main street buildings, are a system of "common" Mitchell would say vernacular - architecture. Building in popular culture should meet the needs and expectations of their popular use. Architecture should not adopt elitist aesthetics in the name of imposing, or correct,

${ }^{23}$ Venturi, Scott Brown, \& Izenour Learning From Las Vegas p 9. social morality. A 1986 letter to the editor of New Zealand Architect, which included a Llew Piper drawing of a giant dog as the "Spotted Dog Restaurant" (the drawing is dated 1944), typifies the extreme interpretation of poparchitecture that misses the point of its revolutionary intent. ${ }^{24}$ Mitchell's architecture does not particularly exhibit the façadist traits of superficial post-modernism, rather collection and collision appear as generative forces.

Closer to the earlier Venturi treatise, Complexity and Contradiction, Mitchell's buildings are more likely to convey interlocking programmatic concerns. Venturi citing Paul Rudolf's critique of Mies, proposed:

All problems can never be solved, indeed it is a characteristic of the twentieth century that architects are highly selective in determining which problems they want to solve. Mies, for instance, makes wonderful buildings only because he ignores many aspects of a building. If he solved more problems, his buildings would be far less potent. ${ }^{25}$

Farrelly's suggestion that The Elegant Shed lacked a clear proposition, can perhaps be

${ }^{24}$ Joyce "In the Dogs House ... [letters]" p 10.

${ }^{25}$ Venturi "Complexity and Contradiction" p 74. explained by Mitchell's post-modern refusal to limit architecture to simple solutions. What needs elaborating however, lies between Post-Modernism as façadism and its more complex articulation in planar modes, as Manning and Mitchell designed the School of Music.

In "Complexity and Contradiction," Venturi was explicit to bracket his form of complexity apart from the picturesque. Formal complexity, for complexity's sake, Venturi argues, is merely picturesque. Mitchell uses a similar tactic in his critique of architects whose designs succeed in formal complexities, which somehow avoids becoming picturesque, while others (such as Dunedin architects McCoy and Wixon) "bring the qualities of Victorian architecture to their own work, occasionally slip[ping] into a picturesqueness that is only superficially agreeable." 26 In a recent historical analysis, John Macarthur argues picturesque concepts persist in twentieth-century Modernism and Post-Modernism, but that it is disguised by a shifting view-point: from the perspectival and scenographic, to the orthographic and

${ }^{26}$ Mitchell Elegant Shed p 78. 
planar view. ${ }^{27}$ In both cases the picturesque defines a visual complexity between figure and ground. While Modernism criticised the scenographic vagueness of picturesque views (e.g. Colin Rowe's Collage City (1975)), Macarthur argues that we can see picturesque complexity transferred to a concern with planning. For Rowe, the historical accrual of buildings in urban contexts forms a collage, readable in plan view as in complexity of roading layouts. Such collage is similar to Mitchell's description of "collisions" in "Slob City Impulse," and like the collage of Modern Art, the collage and collision in architecture invites simultaneous readings. As Rowe writes:

because collage is a method deriving its virtue from its irony, because it seems to be a technique for using things and simultaneously disbelieving in them, it is also a strategy which can allow Utopia to be dealt with as an image, to be dealt with in fragments without our having to accept them in toto. ${ }^{28}$

Macarthur, quoting from William Ellis, explains that images that can be seen from the view of the plan are hidden at the level of occupation: the building may be a dog, but it

\footnotetext{
${ }^{27}$ Macarthur Picturesque pp 224-225.

${ }^{28}$ Rowe Collage City p 149.
}

shall not appear so. Mitchell alludes to similar evasions in architecture when he states:

It might seem unsporting in a time when "multi-valent meanings," historical references, masks and jokes are the substance of architectural fashion, to question whether there is an inner logic to [a] building; or if there is, to question whether the building might not have lost its central voice in a clamour of architectural noise ... That is a post-modern fascination. It shows in the Auckland Music School building, and it is part of a current interest in making architecture that is not what it appears to be..$^{29}$

Farrelly also cushioned her critique by asking if she was being unsporting in asking The Elegant Shed to exhibit a "valiant idea," but now, as in buildings we expect the elegant shed is playing at not what it appears to be. The Music School building presents elegant, but fairly innocuous elevations, particularly by post-modern standards. What it appears to be is a Mediterranean style courtyard, but what it hides in its plan is another story. In the most common story, the plan hides a piano; and pianos haunt Mitchell and the representations of his other architecture. Photographed in Architecture New Zealand for the 1986 award, a grand piano is ominously

${ }^{29}$ Mitchell Elegant Shed p 100. included in high view of the performance theatre. In his 2009 design with Julie Stout for the "Thinking Room" an entire room is dedicated just to the piano. On visiting the building for this paper, just inside the door was a collection of three piano harpsichords, as if because of the permitting space, the occupants had to improvise in order to continue the joke hidden in plan.

I have never actually understood the piano yes there is a curve in the façade, but none of this looks particularly piano-like to me. In the 1986 essay "Schola Musica," Kent Dadson described the design as "three concurrent symphonies interlocking in the shape of a human ear." As a protrusion of skin, flesh and cartilage, the ear is also the second most identifiable part of the human body after finger prints. So yes, I could find ears that replicated the form of the Music School's amphitheatre seating, and if you had the right sort of ear, it might also fit the curve of the outer wall to Symonds Street. Looking forward to the individualist expression of deconstructive architecture, for example, Daniel Libeskind's Berlin Jewish Memorial Museum of 1988 to 2000, the Music School as an ear may express a similar desire to produce autobiographical architecture; 
building as self portrait. However this does not really wash well with Mitchell's apparent modesty, or perhaps more importantly, how he values vernacular and popular culture. As he stated in the Elegant Shed: the importance of the new New Zealand "paper" architecture was in its ability to present the possibility of an art of popular culture to "monumentalize ... the processes of everyday life in this country;"30 closer to Ashton Raggatt McDougal's design for the National Museum of Australia (2000), with its citations of familiar architecture, and its hidden knot.

Because this paper addresses PostModernism, and because it had always niggled, that piano plan, I went looking instead for my own symbolism: a guitar, not just one but ten. The song "Ten Guitars," composed by Engelbert Humperdinck, was popularised in the 1960s in New Zealand culture, particularly by Māori. Michael Parekōwhai monumentalised the song in a sculpture of the same name in 1999. What began as a flippant exploration produced alarmingly consistent result. Centring a standard acoustic guitar on the plan's circular court, and enlarging the guitar repeatedly by

${ }^{30}$ Mitchell Elegant Shed p 110.
$11 \%$, eventually resulted in the seventh guitar sitting snugly against the curve of the outer façade wall. By reproducing the guitar three times at smaller scales, I could fabricate the narrative of ten guitars.

This little experiment does not pretend to present itself as truth, nor intended to be in anyway a derogatory criticism of the School of Music, a building which I have always loved. Rather it is a suggestion, that the value of Post-Modern architecture, in its best sense, is how it can accommodate complex and diverse inhabitation. With a bit of humour, in the curving lines, like a plot line, stories can be gathered and held. The totalising vision of Modernism attempted to make architecture, the world, the future, conform to a singular pattern. Utopian optimism is not missing from PostModernism; ethics and aesthetics were not wholly expedient to commercial demands. Rather it presents a fragmented vision like the view through a kaleidoscope.

Under the pohutukawas in the beach is a sodden Chesterfield suite. Paradise begins to look like a scene from The Bed-Sitting Room. Some kind of shelter seems to be necessary after all. Pretty soon the elegant shed is floating up in the mind's eye, distant and difficult and always just out of focus and just out of reach. But worth searching for. ${ }^{31}$

${ }^{31}$ Mitchell Elegant Shed $\mathrm{p} 9$. 


\section{REFERENCES}

"Awards" Mitchell $\mathcal{E}$ Stout Architects http://www.mitchellstoutarchitects.co.nz/Awards.htm

Dadson, K. "Schola Musica" New Zealand Architect (November/December 1986) $6: 34$.

Exquisite Apart: 100 Years of Architecture in New Zealand. ed. Charles Walker, Auckland, N.Z: Balasoglou Books, 2005.

Farrelly, E. "At Last - the great New Zealand Hovel; The Elegant Shed NZ Architecture Since 1945 by David Mitchell and Gilian Chaplin (OUP 1984)" New Zealand Architect (March/April 1985) 2:39-40.

Joyce, Valentina "In the Dogs House [letters]" New Zealand Architect (1986) 6:10.

Macarthur, John. The Picturesque: Architecture, Disgust and Other Irregularities. Classical tradition in architecture. London: Routledge, 2007.

Manning/Mitchell Architects, "A.H.I. Fibreglass Environmental Design Award 1987, Report" New Zealand Architect (November-December 1986) 6:21-23.

Manning, Mitchell and Hill Architects, "Faculty of Music Building, University of Auckland" New Zealand Architect (September/December 1981) 5/6:1-3.

Matthewson, Gill, Personal communication, 6 November 2009.

Mitchell, David "Looking Inwards" Architecture New Zealand (January/February 2004) 1:25-31.

Mitchell, David "Slob City Impulse" (1979) Douglas Lloyd-Jenkins (ed). New Dreamland: Writing New Zealand Architecture Auckland, N.Z.: Godwit, 2005:266-271.

Mitchell, David and Gillian Chaplin The Elegant Shed: New Zealand Architecture Since 1945. Auckland, N.Z: Oxford University Press, 1984.
Robertson, Graeme, "Appraisal of the School of Music" New Zealand Architect (November/December 1986) 6:24-25.

Rowe, Colin Collage City. Cambridge, Massachusetts: MIT Press, 1978.

Skinner, Robin "The Whare in the Bush: Unpacking a Twentieth Century Tradition" Fabrications (2008) 18(1):56-73.

Venturi, Robert, Denise S. Brown, \& Steven Izenour Learning from Las Vegas: the forgotten symbolism of architectural form Revised edition (June 15, 1977), Cambridge, Massachusetts.: MIT Press, 1977; first published 1972.

Venturi, Robert "Complexity and Contradiciton in Architecture: Selections from a forth coming book" Theorizing a New Agenda for Architecture: An Anthology of Architectural Theory 1965-1995. ed. Kate Nesbitt, New York: Princeton Architectural Press, 1996:72-77.

Walker, Paul "University of Auckland Music School: a blank wall" New Zealand Architect (November/December 1986) (6):33

Wichtel, Diana "Making places sing" New Zealand Listener 27 August 2005)

http://www.listener.co.nz/issue/3407/features/4588/making_places_si ng.htm.

Wood, Peter "Watershed: of buildings and stories and elegant sheds" Charles Walker (ed). Exquisite Apart: 100 years of Architecture in New Zealand Auckland: Balasoglou Press, 2005:72-81. 